\title{
Ortaokul Matematik Öğretmen Adaylarının Üçgen Eşitsizliğini Toplu Argümantasyonla Kavrayışları
}

\section{Tuğba UYGUN}

Alanya Alaaddin Keykubat üniversitesi, Eğitim Fakültesi, Alanya/Antalya, Turkey.

\section{Didem AKYÜZ}

Orta Doğu Teknik Üniversitesi, Eğitim Fakültesi, Ankara, Turkey.

\section{Öz}

Bu çalışmanın amacı, ortaokul matematik ögretmen adaylarının üçgen eşitsizliğiyle ilgili düşünce ve ögrrenmelerini toplu argümantasyon yoluyla nasıl geliştirdiklerini incelemektir. Veri toplama süreci toplu sınıf tartışmaları, akran grubu tartışmaları ve yazılı belgeler üzerine kurulmuştur. Tartışma süreci Toulmin'in argümantasyon modeli kullanılarak analiz edilmiştir. Katılımclar kolektif tartışma süreci boyunca, üçgen eşitsizliği konusundaki geometrik fikirlerini öne sürerek ve bunları sorgulayarak gerekli bilgi ve kavrayışa ulaşmışlar ve nihayetinde bu kavram hakkındaki bilgilerini ve kavrayışlarını geliştirmişlerdir. Katılımaların, ügen eşitsizliği konusundaki bilgi ve kavrayışlarını, matematiksel fikirlerini argümantasyon yoluyla yeniden değerlendirerek geliştirdikleri görülmüştür.

Anahtar Kelimeler: Argümantasyon, ortaokul matematik ögretmen adayı, sosyal öğrenme ortamı, üçgen Eşitsizliği.

\section{İnönü Üniversitesi \\ Eğitim Fakültesi Dergisi \\ Cilt 20, Sayı 1, 2019}

ss. $27-41$

DOI: 10.17679/inuefd.333720

\section{Önerilen Atıf}

Uygun, T. \& Akyüz, D. (2019). Ortaokul matematik öğretmen adaylarının üçgen eşitsizliğini toplu argümantasyonla kavrayışları. Inönü Üniversitesi Eğitim Fakültesi Dergisi, 20(1), 27-41. DOI: 10.17679/inuefd.333720 


\section{GENIŞ ÖZET}

Giriş

Argümantasyon yoluyla, öğrenciler, matematiksel ifadeleri paylaşarak, analiz ederek ve tartışarak geometrik kavramları anlayabilir ve öğrenebilirler. Bu bağlamda, tartışmaların, öğrencilerin matematiksel konuları kavramalarını ve sorgulamalarını, matematiksel fikirlerini paylaşarak, zorlayarak ve iletişim kurarak anlamalarını kolaylaştırdığı söylenebilir. Yapılan Argümanların belirli kavramlar hakkında matematiksel anlayış üzerindeki etkisini araştırmaya hala ihtiyaç vardır. Bu nedenle, bu çalışma, ortaokul matematik öğretmen adaylarının üçgenlerde eşitsizlik kavramını sınıf tartışmalarının yer aldığı öğrenme ortamında matematiksel argümanlar yoluyla anlamasını incelemek ve geliştirmek üzerine yoğunlaşmıştır. Öğretmen adayları tartışmalara katılarak açıklamalarının doğru ve yanlış bölümlerini belirlerler ve fikirleri üzerinde düzeltme yaparak ve doğru ifadeleri oluşturarak doğru matematiksel fikrelere ulaşabilirler.

\section{Çalışmanın Amacı}

Bu çalışmada ortaokul matematik öğretmen adaylarının matematiksel kavramları anlamalarını toplu sınıf tartışmalarında oluşturdukları argümantasyonlara odaklanarak incelenmiştir. Ayrıca çalışmada geometrisel kavramlardan biri olan üçgen eşitsizliği ile ilgili kavramsal anlayış araştırılıştır. Başka bir ifadeyle, bu çalışmanın amacı, ortaokul matematik öğretmen adaylarının (OOMÖA) toplu argümantasyon yoluyla üçgen eşitsizliğini anlamalarını ve kavrayışlarını nasıl geliştirdiklerini incelemektir.

\section{Yöntem}

Katılımcılar üçgen eşitsizliği ifadesinin doğruluğunu tartışmışlardır. Bu çalışmada, nitel bir araştırma tasarımı olarak durum çalışması, öğretmen adaylarıın bu geometrisel kavram ile ilgili kavramsal anlamalarını ve bu anlayışlarını geliştirmelerini etkin bir şekilde incelemek amacıyla kullanılmıştır. Veri toplama sürecinde toplu sınıf tartışması, akran grubu tartışmaları ve yazııı belgelere odaklanılmışır. Sınıftaki toplu tartışmayı matematiksel söylemler araclığılla ortaokul matematik öğretmen adayları, üçgen eşitsizliğinin doğruluğunu anlamak için üretilen fikirler hakkında tartışmışlardır. Sınıfta, eğitmen, ortaokul matematik öğretmen adaylarından üçgen eşitsizliğinin doğruluğunu göstermelerini ve akranlarıla birlikte çalışmalarını istemiştir. Öğretmen adayları akranları ile soru üzerinde çalışıken eğitmen, potansiyel bilgi, hatalar, zorluklar, farklı çözümler ve ifadeleri belirlemek için bu küçük grupları gözlemlemiştir. Gözlem sırasında öğretmen adaylarının olası fikirleri hakkında bilgi edinen eğitmen, öğretmen adaylarının üçgen eşitsizliği hakkında kapsamlı ve doğru bilgiyi edinmelerine yardımcı olmak amacıyla tartışmayı başlatmış ve yönlendirmiştir. Eğitmen, tartışmayı öğretmen adaylarına üçgen eşitsizliği ifadesinin ne anlama geldiğini ve bu ifadenin doğruluğunu nasıl gösterebileceklerini sorarak başlatmıştı. Daha sonra, öğretmen adayları üçgen eşitsizliğinin açıklamasının doğru olduğunu belirtmişler ve böylece tartışmanın iddiasını öne sürmüşlerdir. Veri analizi sürecinin odağı, kolektif sınıf tartışmalarının ve akran tartışmalarının video kayıtları yoluyla toplanan verilere dayanmaktadır. Sınıfta eğitmen ve ortaokul öğretmen adaylarının davranışlarıyla toplu tartışmalar ve bütün sınıf tartışmaları da dahil olmak üzere sosyal öğrenme ortamını kaydetmek için bütün tartışma süreci iki video kamerayla kaydedilmiştir. Yazııı belgelerle tartışma sürecinin döküman haline getirilmiş hali, Toulmin'in argümantasyon modeli kullanılarak analiz edilmiş̧ir.

\section{Bulgular}

Bulgulara dayanarak, toplu öğrenme ortamında sınıf tartışmaları yoluyla farklı düşünme ve sorgulama yollarının çıkarılabileceği gözlemlenebilir. Bu çalışmada gözlemlenen tartışma süreci ile ortaokul matematik öğretmen adaylarının, aynı iddia ve verileri üretmiş olsalar da, üçgen eşitsizliğinin doğruluğunu dört farklı yolla farkı bağlamlar ve destekleyiciler sağlayarak göstermişlerdir. Öğretmen adayları fikir birliğine ulaşıncaya kadar tartışma sürecinde iddia edilen ve üretilen fikirleri analiz etmişler ve sorgulamışlarıdr. Böylelikle, üçgen eşitsizliğini etkili bir şekilde kavramışlardır. Tartışma sürecinde, ortaokul matematik öğretmen adayları arkadaşları tarafından öne sürülen açıklamaları ve bu açıklamaların gerekçelerini dinleyerek ve analiz ederek daha derin bir anlayış kazanmışlar ve muhakeme etme becerilerini geliştirmişlerdir. Bu kolektif argümantasyon sürecinde, öğretmen adayları üçgen eşitsizliği konusundaki geometrik fikirlerini öne çıkararak kavramla ilgili doğru bilgi ve anlayışı kazanmışlar ve nihayetinde bu kavram hakkındaki bilgilerini ve anlayışlarını geliştirmişlerdir. Bulgular düşünüldüğünde, ortaokul 
matematik öğretmen adaylarının, üçgen eşitsizliği konusundaki bilgi ve anlayışlarını matematiksel fikirlerini analiz ederek sınıf tartışmaları yardımı ile geliştirdikleri tespit edilmiştir.

\section{Tartışma ve Sonuç}

Ortaokul matematik öğretmen adaylarının toplu argümantasyon yoluyla üçgen eşitsizliği hakkındaki bilgileri anlamaları ve anlayışlarını geliştirmeleri, bu çalışmada farklı stratejiler ve yollarla incelenmiştir. Bu şekilde, ortaokul matematik öğretmen adayları fikirlerini eğitimcinin rehberliğinde açıklayarak kavramları doğru bir şekilde tanımlamışlardır. Örneğin, iki ortaokul matematik öğretmen adayı, üçgen eşitsizliğinin doğru açıklamasını birlikte oluşturmuşlardır. Buna ek olarak, farklı stratejilerle ve akıl yürütme ile farklı yollarla açıklamalarının doğruluğuyla açıklamalar yapmışlardır. Tartışmada, üçgen eşitsizliğinin doğruluğunu göstermek için birbirlerinin fikirlerine, sorgulamalarına ve stratejilerine itiraz etmişlerdir. Ayrıca, tartışmalarda üzerinde durulan matematiksel fikirlerin, katılımcıların geometrik düşüncelerini ve üçgen eşitsizliği ile ilgili sahip oldukları bilgilerini geliştirdikleri gözlenmiştir. Olkun ve Toluk (2004) tarafından yapılan çalışma da bu bulguyu desteklemektedir. Literatürde yer alan önceki çalışmalar, derslerde yapılan tartışmaların öğrencilerin geometrik düşünce ve sahip oldukları kavramsal bilgileri geliştirdiğini ve argümantasyonların problem çözme, bilimsel düşünme, eleştirel düşünme ve doğrulayıcı ifade sunma becerileri ile kavramsal anlayışı ve bilgi üretimini teşvik ettiğini ortaya koymaktadır (Abi El-Mona ve Abd-ElKhalick, 2011; Duschl \& Osborne, 2002; Jim'enez-Aleixandre 2000, Jonassen ve Kim, 2010; Osborne, Erduran, \& Simon, 2004; Zembaul-Saul, 2005). 


\section{Preservice Middle School Mathematics Teachers' Understanding of Triangle Inequality through Collective Argumentation}

\section{Tuğba UYGUN}

Alanya Alaaddin Keykubat University, Faculty of Education, Alanya/Antalya, Turkey.

\section{Didem AKYÜZ}

Middle East Technical University, Faculty of Education, Ankara, Turkey.

\begin{abstract}
The purpose of the present study was to examine how preservice middle school mathematics teachers develop the understanding and reasoning of triangle inequality through collective argumentation. Data collection process was based on whole class and peer group discussions and written documents. The data including the transcriptions of the discussion processes with the written documents were analyzed by using Toulmin's model of argumentation. Through this collective argumentation process, they attained the knowledge and understanding of triangle inequality by suggesting and challenging their geometrical ideas about the concept and they developed and constructed their knowledge and understanding of this concept. It was found that the participants improved their knowledge and understanding of triangle inequality by argumentation through criticizing their mathematical ideas.
\end{abstract}

Keywords: Argumentation, preservice middle school mathematics teachers, social learning
İnönü University

Journal of the Faculty of Education

Vol 20, No 1, 2019

pp. 27-41

DOI: 10.17679/inuefd.333720

\section{Suggested Citation}

Uygun, T., \& Akyüz, D. (2019). Preservice middle school mathematics teachers' understanding of triangle inequality through collective argumentation, Inonu University Journal of the Faculty of Education, 20(1), 27-41. DOI: 10.17679/inuefd. 333720 


\section{INTRODUCTION}

Many studies explain that the students do not tend to reach the desired level of geometry knowledge and they do not represent expected behaviors in geometry classrooms because of the teachers' insufficient level of geometry knowledge (Clements \& Battista, 1992). Hershkowitz and Vinner (1984) also state that teachers form the students' knowledge of geometry and determine their level of geometry achievement. They provide the evidence for this view by explaining that students tend to show similar misconceptions, procedures and understanding of geometry with their mathematics teachers. Hence, it can be stated that teachers' knowledge and understanding on the content becomes important since it can affect the students' reasoning on geometry, geometrical activities, geometry achievement and classroom interactions (Muijs \& Reynolds, 2002). Therefore, mathematics teachers are expected to have deep knowledge of geometry that they learn in their classrooms. In other words, they must be graduates of teacher education programs by attaining deeper knowledge of geometry required to use in the future as actual teachers. Hence, it is necessary to determine preservice middle school mathematics teachers' (PMSMT) existing knowledge of geometry and to help them develop their understanding about geometry concepts.

The learners can acquire necessary knowledge and skills by participating in discussions. At this point, argumentations are useful since they facilitate the formation of effective discussions, criticizing, explaining and convincing others about the one's ideas. Argumentation also encourages geometrical reasoning since it contains a group of intents and reasoning about in order to state or justify a conclusion or support validity for a conjecture (Flores, 2007). Moreover, it improves reasoning by supporting various elements of verification, explanation, systematization, discovery, communication and intellectual challenge in order to develop their reasoning on geometry (Hadas, Hershkowitz \& Schwartz, 2000). These elements are observed in the classroom environment in which the argumentation takes place since the learners communicate their knowledge and ideas to explain and confront them. This convincing process reveals the learners' misconception, prior knowledge and reasoning to reach a judgment on appropriateness or inconsistency of an argument as a geometrical engagement produced intellectually. Also, learners reorganize their own understanding by participating in collective learning environments including argumentations (Driver, Newton \& Osborne, 2000; Nussbaum \& Bedixen, 2003). They understand the concept and the topic of the lesson with the help of argumentation based on their re-arrangements of their individual understanding considering local social cases in which they occur (Cobb, Gravemeijer, Yackel, McClain, \& Whitenack, 1997). Hence, it can be claimed that through argumentation, learners can understand and learn the geometrical concepts by sharing, analyzing and discussing their mathematical expressions. They determine accurate and wrong parts of their explanations so that they can reach correct mathematical ideas by making revisions on their ideas and forming correct expressions.

Based on these explanations, this study focused on the development of the PMSMT's understanding on the specific geometry concept in a learning environment including discussions. Triangle inequality was selected as the specific content of the study and the classroom discussions and argumentations. It is the content that students are familiar with but they can have difficulty in transferring it into problem situations, reasoning on and justifying. Hence, it requires attention in order to examine their understanding of triangle inequality. Another focus point of the study was their argumentations since the geometry knowledge can be developed by reasoning and argumentation providing opportunities to analyze and comprehend the content (Uygun \& Akyuz, 2019). The previous research show that argumentations as a methodological media are useful in order to determine and represent the collective learning in a classroom. The researchers of these studies provide this representation by documenting changes occurring in the classroom in the period of instruction. In this respect, the PMSMT's understanding about triangle inequality can be examined and developed effectively with the help of argumentation. Argumentation was also used as a tool to analyze the PMSMT's understanding of triangle inequality in a geometry course including social environment in the present study. To this end, it is important to question how the PMSMT develop their understanding of triangle inequality through whole class discussions including argumentations. This question formed the focus of the present study. In other words, in the current study, PMSMT's understanding of and reasoning about triangle inequality through whole class discussion was examined by argumentation.

\section{Argumentation in Mathematics Education}

The concept of the argumentation can be explained as a "social phenomenon, when cooperating individuals tried to adjust their intentions and interpretations by verbally presenting the rationale of their actions" (Krummheuer, 1995, p. 229). It represents a process including try-outs made by students in order 
to convince others about a claim or an idea. Through mathematical argumentations, students can understand a mathematical concept by sharing, discussing and revising their ideas with a common or shared understanding. Such understanding based on mathematical argumentations is encouraged by justifications, active negotiation and revisions for mathematical ideas or claims through mathematical discussions (Forman, Larreamendy-Joerns, Stein, \& Brown, 1998).

Argumentation represents the ways of formation of mathematical justifications and ideas in the communications. Emergence of mathematical arguments is related to the understanding of mathematical concepts in a social learning environment (Lampert, 1990). In this environment, the students challenge, understand and justify their mathematical ideas (Andrews, 1997; Owen, 1995; Van Zoest \& Enyart, 1998). In this way, it is useful to provide conceptual understanding by preventing learning with memorization. In other words, students tend to memorize rules and theorems without questioning and being aware of the ways of using them in their learning of mathematics, especially in geometry. This case can be prevented by mathematical argumentations because the students can learn the mathematical knowledge and skills effectively since they learn the concept by explaining, analyzing, discussing and criticizing with the help of argumentations (Cobb, Wood \& Yackel, 1991; Leonard, 2000; Stein, 2001). By doing so, they can acquire the necessary knowledge by examining the concepts deeply and effectively using critical thinking skills of argumentation. Using argumentations, the learners criticize, analyze, understand and explain the idea so that they can acquire and understand knowledge effectively (Forman et al., 1998). Thus, students learn the mathematical concept so that their learning can be examined based on conceptual changes happening through argumentations (Abi-El-Mona \& Abd-El-Khalick, 2011; Jonassen \& Kim, 2010). In this respect, it can be stated that argumentations are useful to improve learners' understanding of mathematical concepts and reasoning by sharing, challenging and communicating their mathematical ideas in the classrooms. There is still a need to investigate the effect of argumentations on mathematical understanding about particular concepts such as quadrilaterals, circles, polygons (Akyuz, 2016; Uygun \& Akyüz, 2019). In this way, implications for designing learning environments about these concepts can be made for the instructors of the lessons. Also, beneficial information can be acquired about teaching and learning these concepts by these studies. Therefore, the current study focused on to examine and develop the PMSMT's understanding of the concept of triangle inequality through mathematical argumentations in collective learning environment.

\section{METHOD}

Case study was used in the present study because of its nature of providing the way of an in-depth understanding of the learning and discussion process (Merriam, 2009). A case study provides the opportunity of making the phenomenon alive and real by identifying and documenting the meanings for the readers (Gall, Gall \& Borg, 2007). The case study design encourages identifying and explaining the holistic and meaningful characteristics of real-life phenomena (Yin, 1984). By this design, the PMSMT's understanding about triangle inequality through collective argumentations could be analyzed and documented.

\section{Participants}

The participants for this study were twenty three preservice middle school mathematics teachers (PMSMT) in the program of elementary mathematics education at a university in the northern part of Turkey. They were selected by convenience sampling strategy. Of these participants, twelve PMSMT were female and eleven were male students. These participants had become familiar with knowledge of geometry related to the concept of triangles since they took the course of Geometry in previous semesters. Each individual was represented by the letter of $S$ and a number under the title of "Findings".

\section{Data Collection}

The data were collected through whole class discussion, audio recordings of peer group discussions and written documents of the PMSMT. In the classroom, the PMSMT worked with their peers on how to justify triangle inequality and then they discussed their ideas in the whole class discussion process. Audio recordings were used in order to collect the data from peer group discussions about the process of forming their ideas with their peers. Also, the whole class discussion was recorded via video camera. The focus point of the data analysis process was on the data collected through video recordings of whole class discussions. The whole discussion process was recorded by two video cameras in order to observe social 
learning environment including whole class discussions and collective argumentations with the behaviors of the instructor and the PMSMT in the classroom effectively. Hence, two video-cameras were placed in front of the classroom and at the back of the classroom. At the end of the whole class discussion, the video-recordings were transcribed verbatim. The researcher participated into whole class discussions and observed the PMSMT through peer group discussions. The PMSMT were kept informed about recording the discussion processes via video-cameras. The video-recordings were also made based on the permissions of the participants. In the classroom, the instructor asked the PMSMT to justify the accuracy of triangle inequality and wanted them to work on it with their peers. While they were studying about the question with their peers, the instructor visited the small groups in order to identify their potential knowledge, errors, difficulties, different solutions and expressions. By obtaining information about them, the instructor started and directed the discussion in order to help them gain comprehensive and accurate knowledge about triangle inequality.

\section{Data Analysis}

The analysis of the PMSMT's understanding of triangle inequality in a social learning environment was performed based on Toulmin's model of argumentation (1969). The transcripts of the data collected through whole class discussion were analyzed by Toulmin's (1969) model of argumentation benefiting from audio recordings of peer group discussions and written documents of the participants in the context of collective argumentation. This model includes four elements which are claim, data, warrant and backing; and the initial three elements represent the core of Toulmin's model. The first element is the claim as the conclusion statement. They represent the ideas stated as correct by students. They are determined more easily than the other elements of the model since they may be a solution for a problem or mathematical statement to be examined and reasoned. The second element is the data as the evidence of these expressions and the statements encouraging the claims. They provide the evidence for the accuracy of the claims. They can represent mathematical procedures, rules, theorems, definitions or connections about the claim. The third element, the warrant, is the statement connecting the data to the claim; the backing is the one encouraging the warrant. It provides relationship between the data and the claim. They encourage this relationship by making necessary explanations for the data. It illustrates the way of connecting the data with the claim by encouraging and justifying the reasons of this connection. The last element is the backing, stating the reasons of acceptance of an argument providing the validity of the claim.

With the aim of supporting reliability and validity, data triangulation technique was used. The data were collected through different sources such as written documents, audio and video recordings (Creswell, 2009/ 2012). Furthermore, member checking strategy was used. In this strategy, the elements of Toulmin's (1969) model of argumentation and the implications made based on these elements based on the data collected from the participants of the study were discussed with them in the study. Then, the PMSMT were asked about the correctness of the interpretations based on their explanations and discussions through the study (Creswell, 2009, 2012).

\section{FINDINGS}

Encouraging the collective argumentation in the classroom with the mathematical discourses, the PMSMT discussed about the triangle inequality in order to understand its accuracy. The instructor initiated the discussion by asking what it meant and how to show its accuracy. Then, they provided the explanation of triangle inequality as the claim.

Instructor: What can you say about triangle inequality?

$S_{1}$ : The sum of the lengths of any two sides of a triangle must be greater than the third side.

$\mathrm{S}_{2}$ : Let me explain it on the lengths of a triangle. Suppose that we have the triangle of $A B C$ with the length of the edges of $|A B|=7,|A C|=11$ and $|B C|=x$. Let's find the maximum value of the length of $|B C|$ $=\mathrm{x}$. We know that the longest side is across from the largest angle in a triangle... (see Figure 1)

Instructor: What do you mean by this figure?

$\mathrm{S}_{2}$ : On this figure, $\mathrm{x}$ attains the value of 18 but this case does not form a triangle. When we make inference for the formation of a triangle based on this case, the maximum value of $x$ is smaller than 18 since $x<11+7$ and then $x<18 \ldots$ (Figure 1 ) 


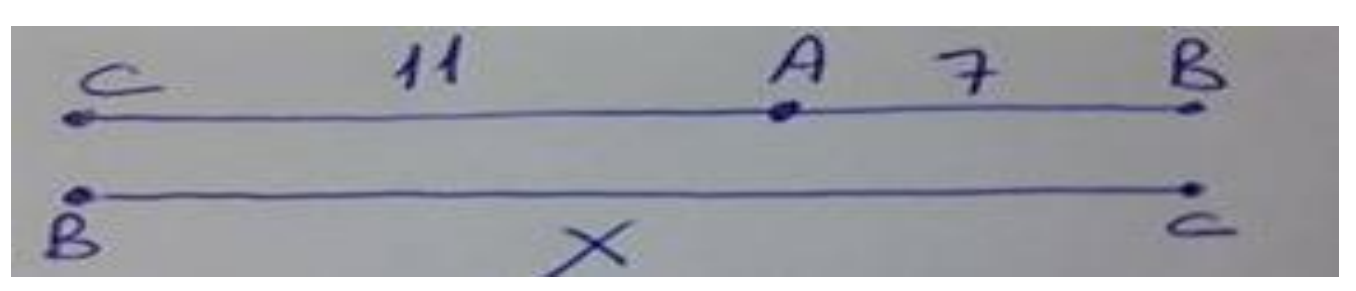

Figure 1. The maximum value for the length of the edge

In this explanation, $\mathrm{S}_{2}$ focused on the connection of angle measure with the length of edge on a triangle. They used the idea that when $x$ attained the maximum value or length, the measure of the angle of $A$ got the maximum value and the measures of the angles of $B$ and $C$ got the smallest values. They also used the idea that $x$ attained the largest value while the measures of the angles of $B$ and $C$ came closer to the value of zero. $S_{2}$ paid attention on the extreme case of angle measure of zero so they examined the case that the angle measures of $B$ and $C$ were zero and formed as in Figure 1. In order to explain this idea by connecting with triangle inequality, $S_{2}$ used the particular lengths as in Figure 1 . Then, $S_{2}$ continued her explanation by stating that the shortest side in length was across from the narrowest angle in a triangle so when $x$ acquired the minimum value or length, the angle measure of $A$ got the smallest value. For example, $x$ attained the smallest value while the angle measure of $A$ came closer to the value of zero as illustrated in Figure 1. This explanation was accurate and necessary for the right hand side of triangle inequality but the left hand side of this inequality was missing. Hence, the instructor directed the discussion in order to help the PMSMT realize this missing part as follows:

Instructor: Is this explanation necessary and sufficient for triangle inequality?

$S_{3}$ : We need to explain the left part of the expression of triangle inequality. The difference of the lengths of any two sides of a triangle must be less than the third side.

Instructor: How can you show the correctness of these explanations?

$S_{3}$ : On this figure, $x$ attains the value of 4 but this case does not form a triangle. When we make inference for the formation of a triangle based on this case, the maximum value of $x$ is larger than 4 since $x$ $>11-7$ and then $x>4$. Therefore, we infer $4<x<18 \ldots$

Instructor: How can you summarize your explanations about the correctness of triangle inequality?

$\mathrm{S}_{3}$ : When we generalize these situations to other triangles having different lengths of edges, we can show triangle inequality...

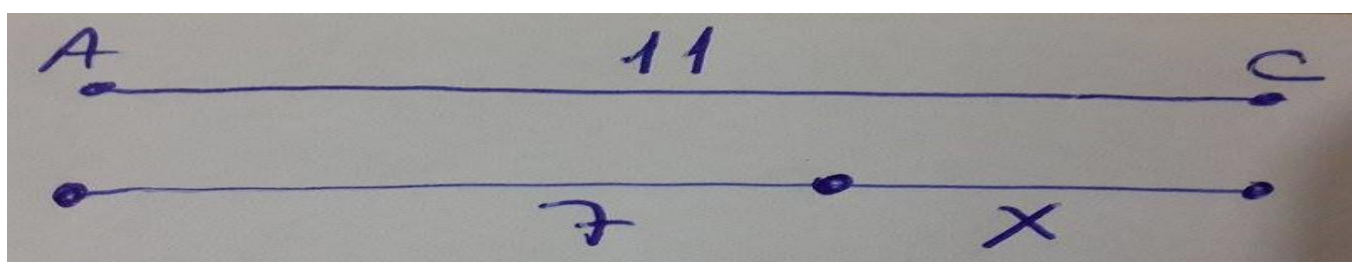

Figure 2. The minimum value for the length of the edge

In this part of the discussion, $S_{3}$ provided the missing part of triangle inequality by using the same mathematical idea about the relationship between angle measure and the length of side on a triangle in the similar way of explanation of $S_{2}$. $S_{3}$ used the idea that the longest side of a triangle took place opposite of the interior angle having largest angle measure in a triangle so then $\mathrm{x}$ as the length of a side acquired the maximum value in length, the measure of the interior angle of $B$ got the largest value. For example, $x$ attained the largest value in length while the angle measure of $B$ came closer to the value of $180^{\circ}$ as illustrated in Figure 2. This explanation was accurate and necessary for the right hand side of triangle inequality. At the end of this part of the discussion, appropriate explanation was provided for the accuracy of triangle inequality.

In this episode of the argumentation, $S_{1}$ explained "the sum of the lengths of any two edges of a triangle must be greater than the remaining edge" and $S_{2}$ made addition for the claim by stating "Moreover, the difference between the lengths of any two edges of a triangle must be less than the remaining one". For this claim, $S_{2}$ and $S_{3}$ provided data based on the knowledge of "When the edge of a triangle gets the maximum value or length, the angle measure of the angle opposite of this edge gets the maximum value 
and the angle measures of the remaining angles of this triangle get the smallest values". $\mathrm{S}_{2}$ provided warrant for this data benefiting from a specific triangle with the length of any two edges with $11 \mathrm{~cm}$ and 7 $\mathrm{cm}$ for the right side of triangle inequality. Then, $\mathrm{S}_{3}$ provided warrant about the left hand side of triangle inequality by reasoning in a similar way. By doing so, $S_{2}$ and $S_{3}$ formed two degenerate cases for the length of the remaining edge of the triangle. In these degenerate cases, they examined the minimum and maximum values of the length of the remaining edge of the triangle. In this episode of the argumentation, they provided warrant benefiting from Segment Addition Postulate although they were not aware of it. They used this knowledge accurately by reasoning through argumentation. Then, the instructor continued the discussion in order to help the PMSMT attain deeper knowledge and understanding of triangle inequality using different strategies.

$S_{1}$ : This is a good explanation for the answer of the question of what it is but I think that we need further mathematical explanation.

Instructor: If so, is there any other explanation?

$\mathrm{S}_{4}$ : We can show triangle inequality by drawing or construction. Suppose that we have three line segments in arbitrary sizes. We can examine it by these line segments. If the triangle is not formed, the constructed shape is not closed on its vertices. We can examine it by using specific lengths from various examples of triangles. For example, suppose that we have these segments. Let's gather these segments on their ends benefiting from circles by using compass and straight edge... (see Figure 3 \& Figure 4)

$\mathrm{S}_{4}$ examined the accuracy of triangle inequality using geometric construction by compass and straight edge appropriately. In her explanation, she studied with the edges of triangles having particular lengths as illustrated in Figure 3. She drew the circles with the radiuses having the lengths equal to these particular edges in Figure 3. She focused on the idea that the intersection points of the circles referred to the vertices of the triangle and the triangle could be constructed by combining these intersection points with line segments. She considered that when these circles did not intersect, the lengths used to construct the triangle did not form a triangle. Hence, this idea was useful to represent the accuracy of triangle inequality. In her explanation, she provided accurate idea for the justification and constructed the triangle by following an accurate way by drawing the circles based on the centers as the end points of the edges of triangle in Figure 4.

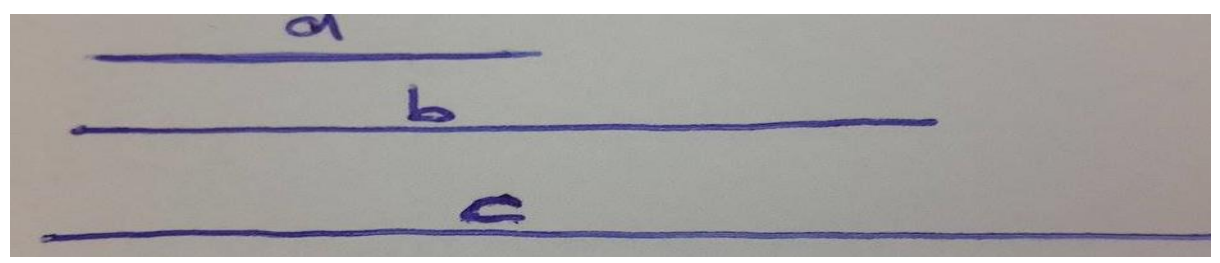

Figure 3. Three line segments with specific lengths

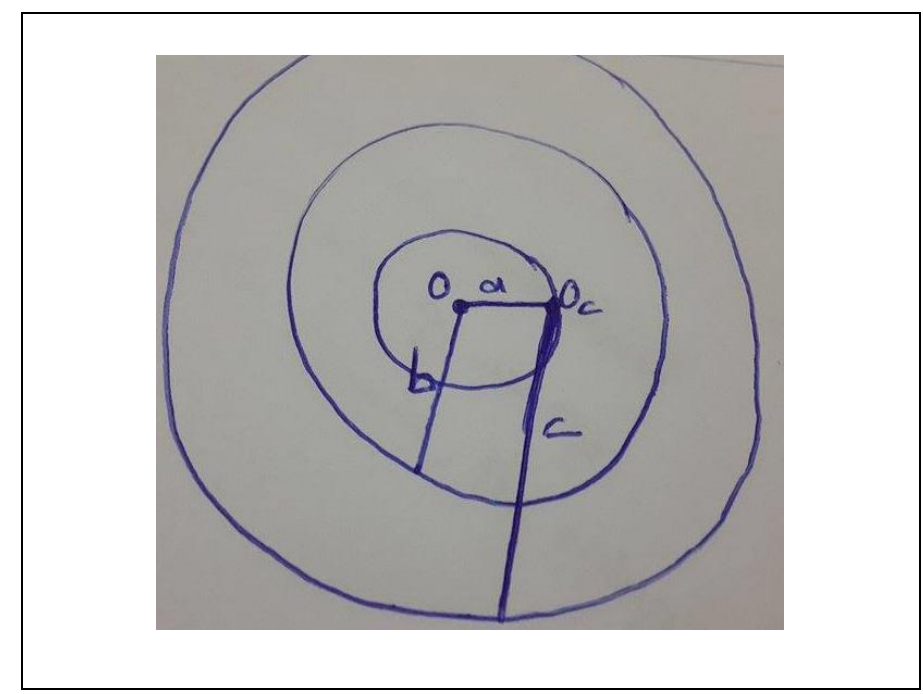

Figure 4. Connecting three line segments on their ends 
After the geometric construction steps explained by $S_{4}$, the instructor guided the discussion to state different construction strategies and form a general statement for triangle inequality as follows:

$\mathrm{S}_{5}$ : ...we must think infinitely many examples of triangles. We have two inequalities for an edge of triangles such $a<c+b$ and $a>|c-b| \ldots$ Suppose we have line segments where $a>b+c \ldots$ We can examine this case with three line segments where $a<|c-b| \ldots$ The true connection is $a>|c-b| \ldots$

$S_{5}$ used the strategy of $S_{4}$ by making more sufficient and accurate explanation. $S_{5}$ focused on two cases of triangle inequality; $a<b+c$ and $a>|c-b|$. She showed the correctness of these two cases representing the left and right hand sides of triangle inequality by assuming that the counter explanations of them were true. As shown in Figure 5, she explained that when the lengths of the edges were connected by $a<b+c$, she examined the case of $a>b+c$. She showed that the circles representing the edges of triangles did not intersect. Hence, a closed figure of triangle could not be formed as illustrated in Figure 5 and it was stated that this part of triangle inequality was $a<b+c$. Then, she studied on the other part of inequality; $a>|c-b|$. She assumed that the counter of it was true; $a>|c-b|$. She tried to construct the triangle in Figure 6 . She could not construct the closed figure of triangle. Therefore, she stated that this part of triangle inequality was $a>|c-b|$ by justifying its accuracy. At the end, she explained and verified that triangle inequality was $\mid c-$ $\mathrm{b} \mid<\mathrm{a}<\mathrm{c}+\mathrm{b}$. In other words, triangle inequality of $|\mathrm{c}-\mathrm{b}|<\mathrm{a}<\mathrm{c}+\mathrm{b}$ was shown and justified by geometric constructions with compass and straight edge.

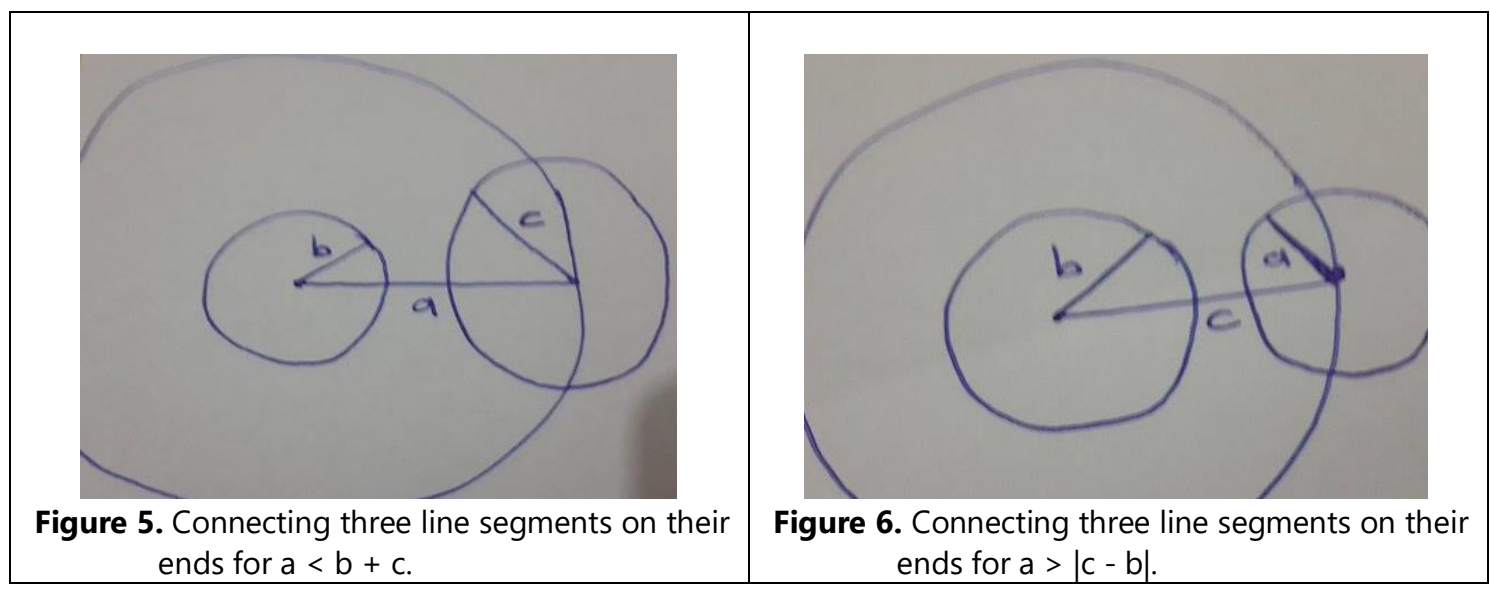

In this episode of the argumentation, $\mathrm{S}_{4}$ provided different strategy for the same claim. She supported her claim by using the definition of a triangle "triangles are the geometrical figures formed by combining three non-linear line segments on their end points as the vertices of the triangle". She explained the warrant by benefiting from using compass and straight edge as geometric construction steps for three line segments. $\mathrm{S}_{5}$ formed two degenerate cases to examine the construction of a triangle based on the length of the edges of triangles for triangle inequality. These degenerate cases included the formation of two triangles with three line segments where $a<b+c$ and $a>|c-b|$ since $|c-b|<a<c+b$ in triangle inequality. In these two degenerate cases, it was shown that the triangles were not formed since opened geometric shapes were constructed. After finishing the discussion about showing the accuracy of triangle inequality by geometric constructions, the instructor continued the discussion by asking another strategy for justification and $\mathrm{S}_{3}$ explained a different way for justification as follows:

$\mathrm{S}_{3}$ : ... by using the shortest distance from any vertex to its opposite edge on the point of $\mathrm{E}$. Let's think on the triangle of $A B C$. We know that the longest side is across from the largest angle in a triangle. Therefore, in the triangle of $A E C,|A C|>|E C|$ and in the triangle of $A B E,|A B|>|B E|$ (in Figure 7). When we repeat them steps for other two edges, we show that the sum of the lengths of any two sides of a triangle must be greater than the third side. 


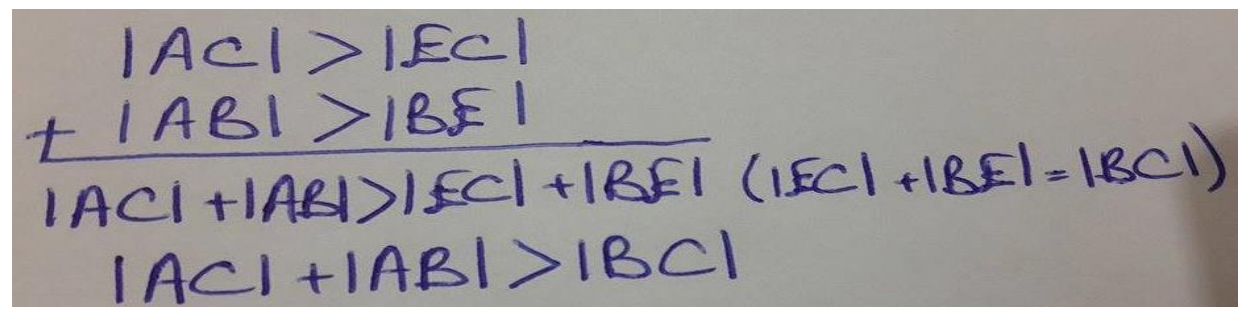

Figure 7. Sum of inequalities

$\mathrm{S}_{7}$ : We show the one side of triangle inequality. We need to show the other side of it related to difference of two edges.

$S_{3}$ : For example, we have $|A C|+|A B|>|B C|$. Let's remove the length of $|A B|$ from both hand sides of inequality. We obtain $|A C|>|B C|-|A B|$. When we repeat these for the others, we show triangle inequality completely.

In this part of collective argumentation process, $S_{3}$ provided different strategy for the claim accurately. He made an explanation based on the mathematical idea about the relationship between the angle measures and the lengths of the edges. He explained this by the knowledge of the shortest distance from a point to a line. This knowledge was transferred to a triangle with the shortest distance from any vertex to the opposite edge of it forming two right triangles in a triangle, and it was also known that the length of a hypotenuse was greater than the lengths of other two edges. For the warrant, the point of the altitude on the edge separated this edge into two parts and by examining two right triangles based on the data provided, the relationship between the lengths of the edges of the triangle was formed. For example, by doing so, he showed $|A C|+|A B|>|B C|$ and $|A C|>|B C|-|A B|$. When this process was repeated for all vertices, triangle inequality was shown. At this part of the argumentation, all of the strategies of the PMSMT formed through peer group discussions finished explaining and sharing them for showing the accuracy of triangle inequality. None of the PMSMT showed the correctness of it by vectors. Then, the instructor wanted to provide justification by algebraic view so the PMSMT were directed to focus on vectors and the sum of them under the guidance of the instructor as follows:

Instructor: Is there any other mathematical explanation? What do you think about triangle inequality by Analytic Geometry?

S6: Actually, the figure of a triangle looks like the sum of two vectors.

Instructor: Well, continue thinking in this way.

$\mathrm{S}_{6}$ : We can show triangle inequality by the sum of two vectors.

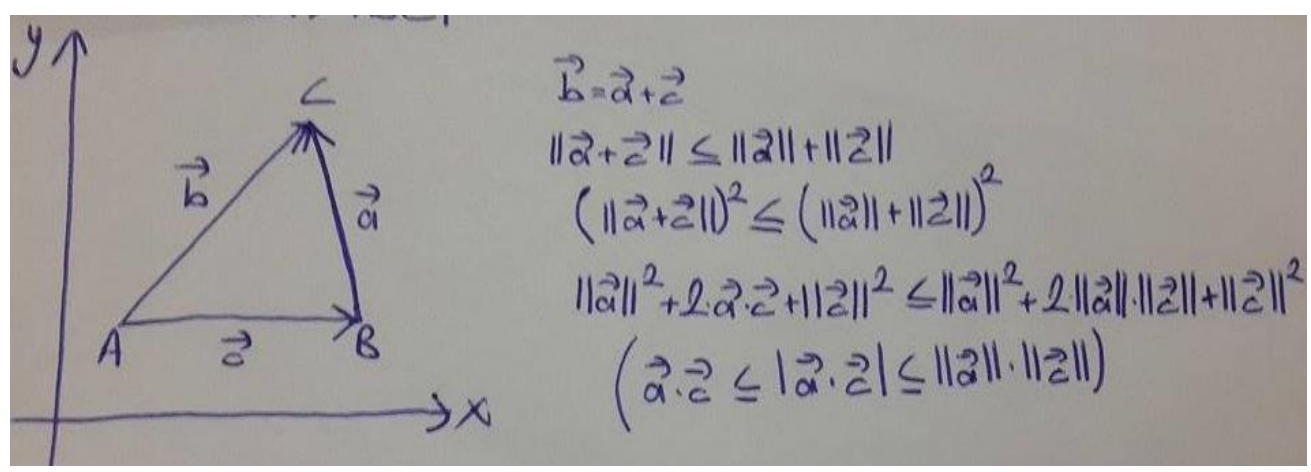

Figure 8. Sum of two vectors.

The instructor helped them to pay attention on the sum of vectors to justify triangle inequality. They considered the edges of triangle as vectors and investigated the formation of triangles based on the sum of them. The justification was explained based on this idea since they assumed that they formed a closed figure of triangle. The last backing for the claim was provided by $S_{6}$ with the clues of the instructor. The data was formed based on the sum of two vectors on the coordinate system. The backing was explained benefiting from the Cauchy Schwartz Inequality although he was not aware of using this inequality. He followed the solution of it by squaring both hand sides of the inequality and ending this solution process. 
In this collective argumentation, the PMSMT discussed about the justification of triangle inequality. Initially, $S_{1}$ and $S_{3}$ provided the claim of the argumentation by explaining the inequality. Then, $S_{2}$ stated the data for that claim based on the idea about the relationship between angle measures and the lengths of the edges on a triangle. They used the idea that a side of triangle having largest value in length took place opposite of the angle with the largest angle measure of the triangle. Hence, the data were stated based on the lengths of the edges. By these data, $S_{2}$ and $S_{3}$ provided warrant by Segment Addition Postulate. These explanations formed the core of the argument. $S_{4}$ and $S_{5}$ provided backing by geometric constructions with compass and straight edge. They examined the possibility of formation of closed figure of triangle by intersection of the circles through constructions. $S_{3}$ provided another backing by the idea about the relationship between angle measures and the lengths of the edges on a triangle. He represented these relationships by the inequalities and then made summations and subtractions between them. By doing so, they justified triangle inequality. Lastly, $\mathrm{S}_{6}$ explained a different baking for the argumentation by the sum of vectors. He investigated the possibility of formation of a closed figure of triangle by the vectors. The discussion part of the current study was represented by the Toulmin's model of argumentation in Figure 9.

\begin{tabular}{|l|l|l|}
$\begin{array}{l}\text { DATA } \\
\mathrm{S}_{2} \text { : Let me explain it on the lengths } \\
\text { of a triangle... We know that the } \\
\text { longest side is across from the } \\
\text { largest angle in a triangle... }\end{array}$ & $\begin{array}{l}\text { CLAIM } \\
\mathrm{S}_{1}: \text { The sum of the lengths of any two sides of a triangle } \\
\text { must be greater than the third side. } \\
\mathrm{S}_{3}: \text {...The difference of the lengths of any two sides of a } \\
\text { triangle must be less than the third side. }\end{array}$ \\
\hline
\end{tabular}

\section{WARRANT}

$\mathrm{S}_{2}$ : On this figure, $x$ attains the value of 18 but this case does not form a triangle. ... the maximum value of $x$ is smaller than 18 since $x<11+7$ and then $x<18 \ldots$

$S_{3}: \ldots$ the maximum value of $x$ is larger than 4 since $x>11-7$ and then $x>4$. Therefore, we infer $4<x$ $<18 \ldots$

\section{BACKING}

$\mathrm{S}_{4}$ : We can show triangle inequality by drawing or construction. Suppose that we have three line segments of arbitrary sizes.

$S_{5}:$... we must think infinitely many examples of triangles. We have two inequalities for an edge of triangles such $\mathrm{a}<\mathrm{c}+\mathrm{b}$ and $\mathrm{a}>|\mathrm{c}-\mathrm{b}| \ldots$

\section{BACKING}

$\mathrm{S}_{3}:$... by using the shortest distance from any vertex to its opposite edge on the point of $\mathrm{E}$. Let's think on the triangle of $A B C$. We know that the longest side is across from the largest angle in a triangle. Therefore, in the triangle of $A E C,|A C|>|E C|$ and in the triangle of $A B E,|A B|>|B E| \ldots$

\section{BACKING}

$\mathrm{S}_{6}$ : We can show triangle inequality by the sum of two vectors.

Figure 9. Toulmin's model of argumentation for triangle inequality

With the aim of providing evidence in order that the PMSMT learned and understood the triangle inequality through collective argumentation, the PMSMT's further discussions and worksheets about other geometrical concepts were examined. In the triangle similarity and congruence concept, they used their understanding about triangle inequality in the discussion about congruence/similarity criteria. They exaplained that ASS is not a criterion using triangle inequality. 


\section{DISCUSSION, CONCLUSION AND IMPLICATIONS}

Based on the findings, it can be observed that different thinking and reasoning ways can be extracted through classroom discussions in a collective learning environment. By the discussion process taking place in the present study, the PMSMT showed the accuracy of triangle inequality in four different ways by providing warrant and different backings although they produced the same claim and data. They challenged their ideas explained by others until reaching consensus about them and comprehended triangle inequality effectively. Through the discussion process, it became possible for the PMSMT to form deeper understanding and reasoning with the explanations and reasoning of others in the discussion. By using the mathematical ideas explained in the discussion, they were able to develop their own ideas, forms of reasoning and solution strategies. Hence, they can develop their comprehension by studying individually and participating in social learning process as suggested in the pervious research of Akyüz (2016). They also produced different ways to show the reasoning and accuracy of the triangle inequality. Moreover, these different strategies have become useful for them to transfer the knowledge of triangle inequality to other situations, mathematical concepts and ideas. For example, they could criticize more effectively and understand the criterion of side-side-side of the similarity and congruence of triangles and the cases about the possibility of construction and drawing of triangles through knowing their two sides' lengths.

The PMSMT's understanding and development of their knowledge about triangle inequality through argumentations were examined by different strategies and ways in the present study. By doing so, they formed accurate knowledge by explaining their ideas under the guidance of the instructor. For example, two PMSMT formed the accurate explanation of triangle inequality together. Moreover, they provided justifications in different ways and by reasoning differently. In the argumentation, they challenged their ideas, reasoning and strategies to show the accuracy of triangle inequality. Also, it was observed that the mathematical discussions including the argumentations improved their geometric thinking and knowledge of triangle inequality in the study. The study conducted to by Olkun and Toluk (2004) also supports this finding. They stated that discussions taking place in the classrooms developed the students' geometric thinking and knowledge. Moreover, previous research indicate that argumentations encourage the conceptual understanding and knowledge production with problem solving, scientific thinking, criticizing and justification skills (Abi El-Mona \& Abd-El-Khalick, 2011; Duschl \& Osborne, 2002; Jim'enez-Aleixandre et al., 2000; Jonassen \& Kim, 2010; Osborne, Erduran, \& Simon, 2004; Zembaul-Saul, 2005). Furthermore, argumentations improve working on mathematics and encourage challenging claims in a social learning environment where the learners communicate and question in order to produce the discourse, learning atmosphere and classroom culture (Abi-El-Mona \& AbdEl-Khalick, 2011). Hence, other mathematical concepts can be focused on in order to improve learners' conceptual understanding and attain deeper knowledge. Therefore, the use of argumentation in different grade level of learners' conceptual understanding and its effects can be explored in various mathematical concepts in further studies. Moreover, the study can be replicated by using dynamic geometry software in further research. Therefore, detailed and various knowledge about the benefits of argumentation in conceptual understanding can be acquired and important contrubitions can be provided to the literature. 


\section{REFERENCES}

Abi-El-Mona, I. \& Abd-El-Khalick, F. (2011). Perceptions of the nature and goodness of argument among college students, science teachers and scientists. International Journal of Science Education, 33(4), 573-605.

Akyuz, D. (2016). Mathematical practices in a technological setting: A design research experiment for teaching circle properties. International Journal of Science and Mathematics Education, 14(3), 549573.

Akyüz, D. (2016). Bir Öğretmen Adayının Çözüm Stratejileri: Sayıları Sekizlik Tabanda Yeniden Keşfetme. Inönü Üniversitesi Eğitim Fakültesi Dergisi, 17(2), 199-216.

Andrews, P. (1997). A hungarian perspective on mathematics education. Mathematics Teaching, 161, 14-17.

Clements, D. H., \& Battista, M. T. (1992). Geometry and spatial reasoning. In D. rouws(Ed.), Handbook of research on mathematics teaching and learning (pp. 420-464). New York: Macmillan.

Cobb, P., Gravemeijer, K., Yackel, E., McClain, K., \& Whitenack, J. (1997). Mathematizing and symbolizing: The emergence of chains of signification in one first-grade classroom. In D. Kirshner \& J. A. Whitson (Eds.), Situated cognition: Social, semiotic, and psychological perspectives (pp. 151-233). Mahwah, NJ: Erlbaum.

Cobb, P., Wood, T., and Yackel, E. (1991). A constructivist approach to second grade mathematics. In von Glaserfield, E. (Ed.), Radical Constructivism in Mathematics Education, pp. 157-176. Dordrecht, The Netherlands: Kluwer Academic Publishers.

Creswell, J. W. (2009). Research design: Qualitative, quantitative, and mixed methods approaches (3rd ed.). Thousand Oaks, CA: SAGE Publications.

Creswell, J. W. (2012). Educational research: planning, conducting, and evaluating quantitative and qualitative research (4th ed.). Thousand Oaks, CA: SAGE Publications.

Driver, R., Newton, P., \& Osborne, J. (2000). Establishing the norms of scientific argumentation in classrooms. Science Education, 84(3), 287-312.

Duschl, R. \& Osborne, J. (2002). Supporting argumentation discourse in science education. Studies in Science Education, 38, 39-72.

Flores, H. (2007). Esquemas de argumentación en profesores de matemáticas del bachillerato. Educación Matemática, 19, 63-98.

Forman E. A., Larreamendy-Joerns J., Stein M. K., \& Brown, C. A. (1998). You're going to want to find out which and prove it. Collective argumentation in a mathematics classroom. Learning and Instruction, 8(6), 527-548.

Gall, M. D., Gall, J. P., \& Borg, W. R. (2007). Educational research: An introduction. Boston: Pearson Education.

Hadas, N., Hershkowitz, R., \& Shwarz, B. (2000). The role of contradiction and uncertainty in promoting the need to prove in dynamic geometry environments. Educational Studies in Mathematics, 44, 127150

Hershkowitz, R., \&Vinner, S. (1984). "Children's concepts in elementary geometry: A reflection of teachers' concepts?" Southwell, B., Eyland, R., Cooper, M., Conroy, J \& Collis, K. (Eds). Proceedings of the Eighth International Conference for the Psychology of Mathematics Education (p. 63-69). Darlinghurst, Austrailia: Mathematical Association of New South Wales.

Jim'enez-Aleixandre, M. P., Bugallo, A., \& Duschl, R. A. (2000). Doing the lesson or doing the science: Argument in high school genetics. Science Education, 84(6), 757-792.

Jonassen, D., \& Kim, B. (2010). Arguing to learn and learning to argue: Design justifications and guidelines. Educational Technology Research and Development, 58, 439-457.

Krummheuer, G. (1995). The ethnography of argumentation. In P. Cobb \& H. Bauersfeld (Eds.), The emergence of mathematical meaning: Interaction in classroom cultures (pp. 229-269). Hillsdale, NJ: Lawrence Erlbaum Associates.

Lambert, M. (1990). When the problem is not the question and the solution is not the answer: Mathematical knowing and teaching. American Educational Research Journal, 27, 29-63.

Merriam, S.B. (2009). Qualitative Research: A Guide to Design and Implementation. San Francisco: JosseyBass.

Leonard, J. (2000). Let's talk about the weather: lessons learned in facilitating mathematical discourse. Mathematics Teaching in the Middle School, 5(8), 518-523.

Muijs, D. \& Reynolds, D. (2002). Teachers' beliefs and behaviors: What really matters? Journal of Classroom Interaction, 37, 3-15. 
Nussbaum, E. M., \& Bedixen, L. D. (2003). Approaching and avoiding arguments: The role of epistemological beliefs, need for cognition, and extraverted personality traits. Contemporary Educational Psychology, 28(4), 573-599.

Olkun, S. \& Toluk, Z. (2004). Teacher questioning with an appropriate manipulative may make a big difference. IUMPST: The Journal, 2, 1-11.

Osborne, J., Erduran, S., \& Simon, S. (2004). Enhancing the quality of argumentation in school science. Journal of Research in Science Teaching, 41(10), 994-1020.

Owen, J. E. (1995). Cooperative learning in secondary schools. London: Routledge.

Stein, M. (2001). Mathematical argumentation: putting umph into classroom discussions. Mathematics Teaching in the Middle School, 7(2), 110-112.

Toulmin, S. E. (1969). The uses of argument. Cambridge: Cambridge University Press.

Uygun, T. \& Akyuz, D. (2019). Developing subject matter knowledge through argumentation. International Journal of Research in Education and Science (IJRES), 5(2), 532-547.

Van Zoest, L.R. \& Enyart, A. (1998). Discourse of course: encouraging genuine mathematical conversations. Mathematics Teaching in the Middle School, 4(3), 150-157.

Zembaul-Saul, C. (2005, April). Pre-service teachers' understanding of teaching elementary school science argument. Paper presented at the Annual Meeting of the National Association for Research in Science Teaching, Dallas.

\section{İletișim/Correspondence}

Dr. Öğr. Üyesi Tuğba UYGUN tugba.uygun@alanya.edu.tr

Doç. Dr. Didem AKYÜZ dakyuz@metu.edu.tr 